\title{
Public safety in monofunctional zones of Vilnius city
}

\author{
Vytautas Bielinskas $^{\mathrm{a}}$, Eugenijus Staniūnas ${ }^{\mathrm{a}}$, Giedrè Beconyte $\dot{\mathrm{e}}^{\mathrm{b}}$, \\ Andrius Balčiūnas ${ }^{b}$, Darius Vasiliauskas ${ }^{b}$ \\ ${ }^{a}$ Department of Urban Engineering, Vilnius Gediminas Technical University, Sauletekio av. 11, 10223 Vilnius, Lithuania \\ ${ }^{b}$ Centre for Cartography, Vilnius University, M.K. Čiurlionio 21, 03101 Vilnius, Lithuania
}

\begin{abstract}
Policies of urban development are developed and come into force in form of laws, planning documents and other legal acts in many European countries. The Declarations of the Rights of the European Human right stresses up the safety and declares the necessity to foster a city, which as far as possible prevents crime, offenses and aggression. Both planners and citizens understand the impact of organization of urban environment to life quality, including safety. The problem is that the relationship between the environment and society is very complex. It is not sufficiently investigated how urban environment changes people who reside and socially interact in that territory and how it affects criminality. Public safety is one of the factors that strongly influence the quality of life. Reduction of crime rate can only be achieved if diverse factors, including characteristics of urban environment, are taken into account. The authors of the paper analysed possible impact of different urban parameters to the distribution and dynamics of crimes in open spaces. A theoretical framework of factors that can influence crimes in public spaces was developed on the basis of the classical 'crime triangle', linking likely offenders, suitable targets and guardians for the targets in time and space. The main initial hypothesis was that functionally homogeneous zones (i.e., 'purely' residential, commercial, or industrial) tend to have significantly higher crime rate than mixed use (polyfunctional) zones. The hypothesis was tested on a densely populated part of Vilnius city - 12 districts with similar morphometric characteristics (density, height and fragmentation) of the built-up areas across the residential zone. The authors have been looking for the relationships between homoand heterogeneity of the land use and varying territorial crime patterns based on more than 10,000 registered criminal incidents of 2012 . The investigation showed that territories with monofunctional commercial use are exposed to the highest risk of all types of crimes in the open space: murders and assaults, robberies and thefts and minor offenses. On the contrary, in the residential zones, less percentage of mixed use means lower crime rate.
\end{abstract}

Keywords: criminality; territorial distribution; functional zones; urban zones; spatial analysis; geographical information systems; Vilnius.

\section{Introduction}

Criminality is a phenomenon with a complex structure, background and causality. It has been deeply investigated in the forensic science. Besides other factors, criminality is influenced by the physical and functional organisation of the living environment. Some authors state that delinquent behaviour is the result of interaction of a person and a combination of environmental factors that strongly influence values and models of social behaviour [1]. The relationships between criminality and physical and functional organisation of the living environment have been investigated in various studies. It can be guessed that human behaviour is influenced by the morphometric parameters of the zone of visibility, structure of street network and infrastructure objects, presence of objects that attract crime, types and functions of urban constructions. Urban criteria were first systematized by Herbert Gans who introduced the concept of 'urban village' model [13] and defined urban parameters that increase the level of safety, such as narrow streets, ample pedestrian space etc. The defensible space theory relates forms of social organization or disorganization to existing socio-urbanistic relationships [16], [22]. The routine activity theory and the crime triangle $[8,9,10]$ consider place and its 'handler' or absence of such. It states that offenders have routine behaviours that lead them to discover favourable territories with attractive targets. Such territories may be formed by urban elements: anonymous, unattended spaces, abandoned buildings, crime attractors [11, 12, 20] tower block of flats with poor observation possibility [6] etc. Formation of strong urban communities is also influenced by morphometric characteristics: low-rise constructions contribute to safer environment [19]. There is opinion that the number and types of crimes vary depending on social status, education, culture of the community, and demographic characteristics

Corresponding author: Vytautas Bielinskas. E-mail address: vytautas.bielinskas@gmail.com

http://dx.doi.org/10.3846/enviro.2014.108

(C) 2014 The Authors. Published by VGTU Press. This is an open-access article distributed under the terms of the Creative Commons Attribution License, which permits unrestricted use, distribution, and reproduction in any medium, provided the original author and source are credited. 
$[5,7,17]$. There are strong reasons to believe that crime prevention through environmental design is also possible $[2 ; 14,15$, $16]$.

Some findings probably are common and applicable for all social groups and types of environment. However, there are many issues that prevent from simple generalization of the relationships. Firstly, different studies of impact of diversity of use yielded controversial results. Some studies show that a diversity of uses, buildings and tenures accommodated within a common street pattern may contribute to greater security throughout the day due sufficient population in the street in the daytime and better surveillance during the night time [4, 21]. On the other hand, some researchers have demonstrated that mixed use increases risk of robberies and in some case assaults and property crimes [18]. Secondly, it remains unclear how the relationship between criminality and environmental characteristics manifests in different cultures, where different cultural groups may exhibit different reactions to the same environment. Thirdly, living environment within one country or a city can substantially differ from living environment of another country or a city. Considering the above, the relationship between urban environment and criminality in the cities may be very individual. Therefore only full and particular research can yield practically applicable results in a concrete case.

Spatial analysis of criminal activities in Vilnius city at large scale began in 2010. The first research [3] revealed the specifics of distribution of different type of crimes and general spatial pattern of criminal activity in the city. The study showed that although number of registered events and criminal incidents strongly depend on population density, crimes of particular types (thefts, violent crimes) concentrate in specific patterns that sometimes are difficult to explain by sociodemographic characteristics alone. For example, some objects, like a marketplace or shopping centre, obviously attract crimes while similar objects in a district with similar characteristics, do not. The authors believe that distribution of crimes in Vilnius is also influenced by immediate urban environment - technogenic and functional characteristics of the environment. In order to test this hypothesis we performed the analysis we present here.

We have analysed the dislocation of criminal events in open area (not inside the buildings) and some characteristics of spatial and functional organization of the place. The territory of the city was divided into $500 \times 500$ meter grid cells for the research purpose. We investigated into functional homogeneity/heterogeneity of the territory combined with morphometric characteristics of the built-up areas and searched for the coincidence of intensity of registered criminal activities and the characteristics of urban environment organization.

\section{Data used in the research and the target area}

Spatial, statistical and cartographic analysis has been performed on several spatial datasets.

Data on criminal events registered during 2012 has been provided by the Vilnius police authorities. After geocoding it contained 20631 record for the entire city. Criminal incidents that are presumably not related to the urban environment (e.g., forgery, bribery, tax evasion, unauthorized access to information etc.) were excluded and the remaining 10107 incidents were grouped by the type of environment: open spaces and other public areas (5451 incident; $54 \%$ ); residential premises (2202 incidents; 22\%); non-residential premises (2454 incidents; $24 \%$ ).

Spatial census data of 2011 available from the website of the Department of Statistics (aggregated by $500 \times 500$ meter grid) have been used to calculate relative crime rate thus eliminating impact of population density. Population data does not include information of daily people's flows, but we assume that they are regular in all the target area. $500 \times 500$ meter grid was used for aggregation of all data.

Digital database of functions in Vilnius buildings has been compiled by the students of Vilnius University following uniform methodology. Data on actual use of premises have been collected and revised in 2009-2013. We have generalized the data to four primary types of use: residential, economic activities (commercial), supplementary/infrastructural use (warehouses, garages, parkings etc.) and unused premises. Then the share of each type in the building was calculated. Unfortunately, the data did not cover Vilnius city consistently. Therefore only the districts where data were uniformly reliable were chosen for the research (Fig. 1). The territory generally can be characterized as rather homogeneous 'sleeping' districts of tower block of flats built in various Soviet periods, except Žverrynas - old, low-rise and prestigious, Šnipiškès and Naujamiestis with their high contrasts and Pašilaičiai and Pilaitė - relatively new, richer and more heterogeneous residential districts. 


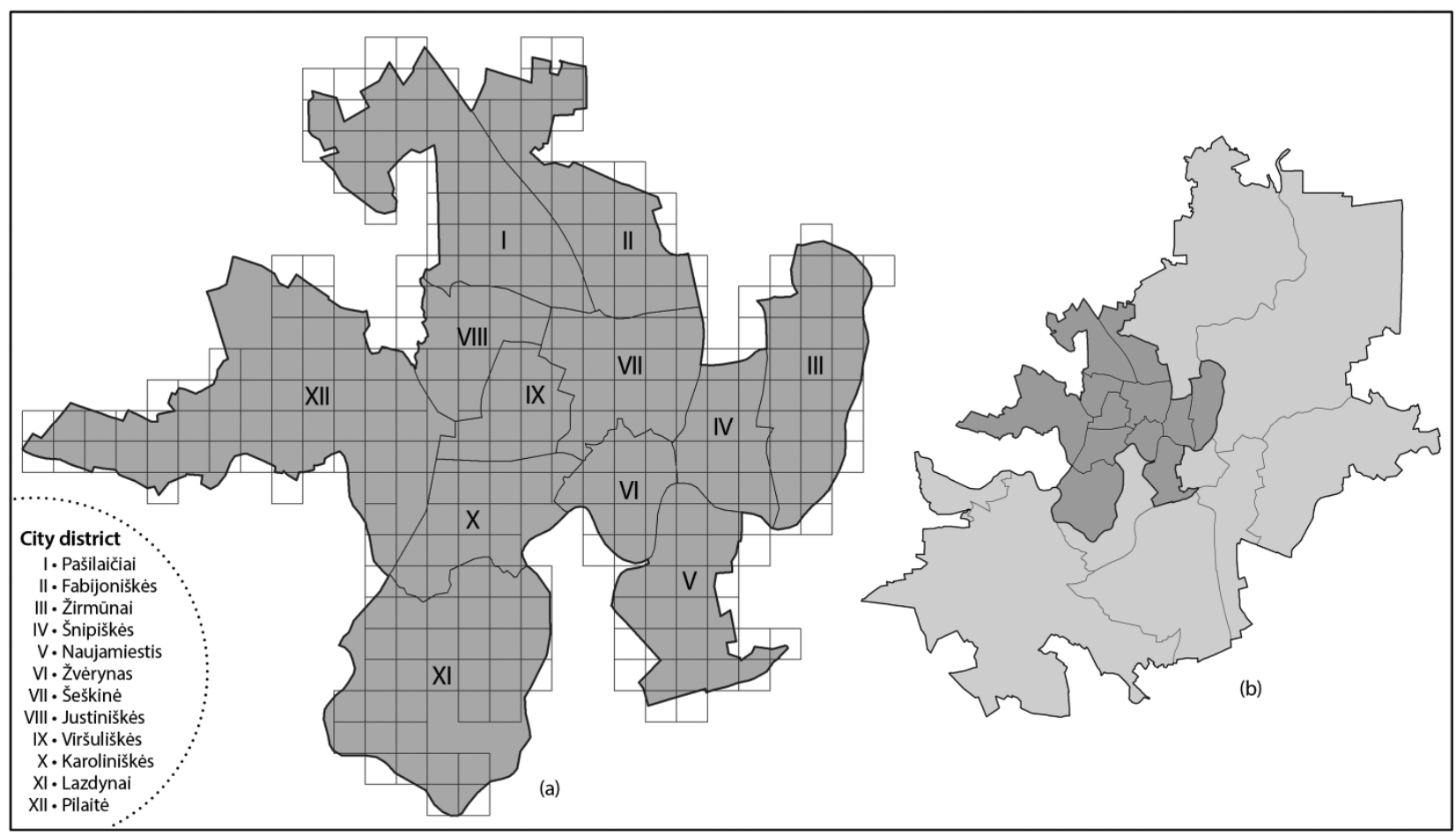

Fig. 1. Target area with the grid for functional zoning (a) and overview map (b)

Information on buildings from the reference base dataset GDR10LT, 2013, available form www.geoportal.lt was used for calculation of morphometric characteristics for each grid cell.

\section{Methods of zoning and analysis}

The target area was divided into 295 cells of $500 \times 500$ meters for aggregation of data on building geometry and the cases of use registered in buildings. According to calculated percentage of floor space occupied by different types of use, 7 types of zones were distinguished (Fig. 2, a): true monofunctional areas where $80 \%$ or more total floor space have same type of use: residential, commercial or supplementary; areas with dominant (60 to 80\%) single type of use, either residential or commercial; bi-functional areas where two types of use (residential-commercial, residential-supplementary and commercial -supplementary) make up about $40 \%$ each and true polyfunctional areas. Unused areas were sporadical, surrounded by large open spaces and were not taken into account. There are only three territories with 'supplementary' type of use, mainly garages, all in the newer part of the target area.

Five density classes from very low to very high compared to the average for the target area were assigned for each cell (Fig. 2, b). Comparison of both maps allows for identifying three basic types of monofunctional zones in the target area: highly concentrated commercial; highly concentrated residential and sparse residential (central part of Pilaitè). Bi- and polyfunctional cells are much more scattered and tend to concentrate in the densely built-up parts of the territory, which are older and closer to the city centre. Single monofunctional commercial use area in the eastern part of the target area is interspersed with small groups of polyfunctional cells. There are several residential zones that can be considered truly monofunctional.

Methods of spatial analysis have been applied considering three requirements:

- Use of factual, not interpolated data;

- Possibility to aggregate point data in small territorial units;

- Possibility to compare characteristics of urban environment, criminality and population density in territorial units of the same size;

In order to comply with these requirements spatial join method was applied for combining all data for the cells of the same $500 \times 500$ grid that has been used for zoning. Cluster and outlier analysis was used for identification of concentration of various types of crimes. 


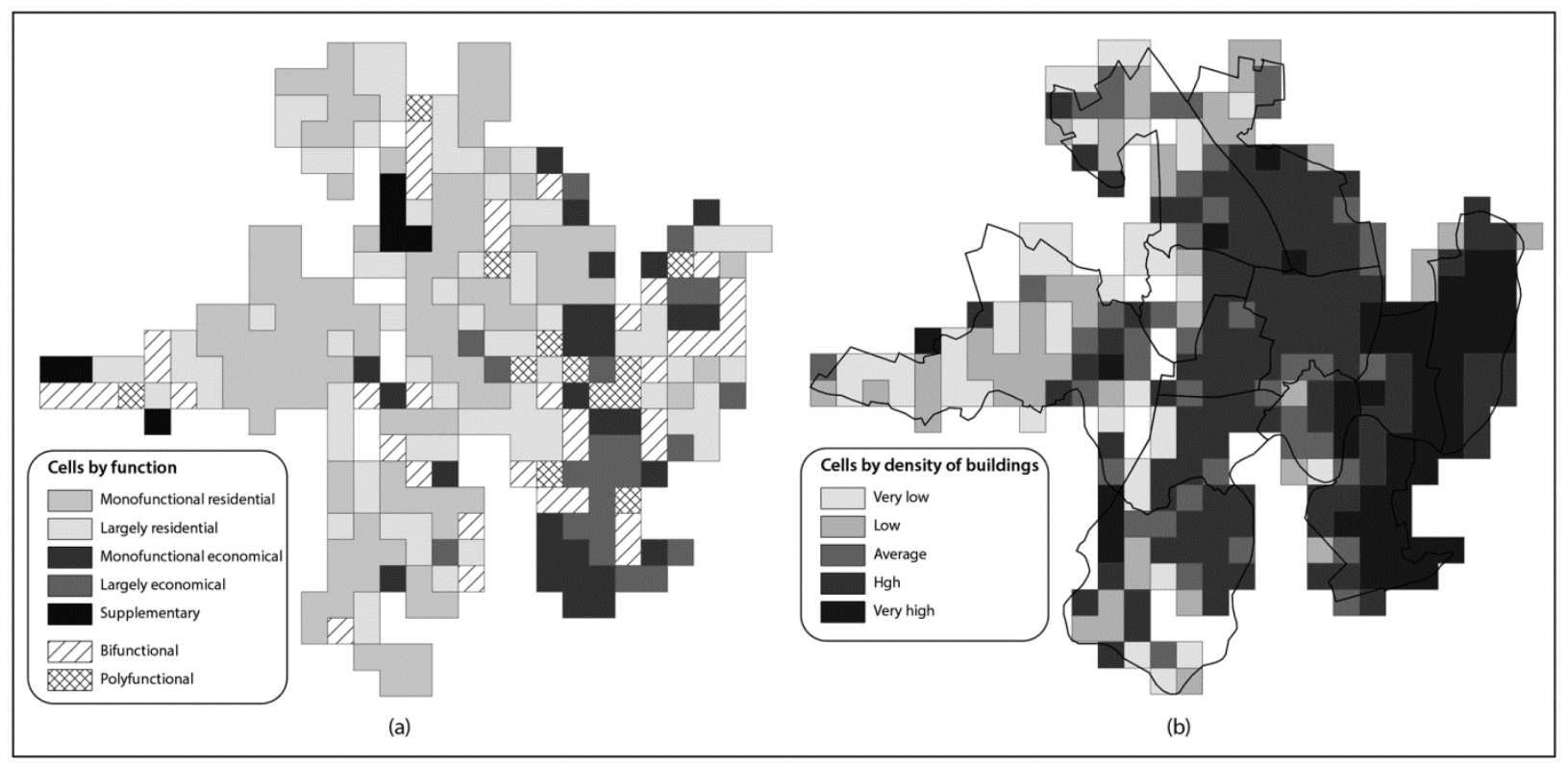

Fig. 2. Use of the territory for different functions (a) and density of buildings (b)

\section{The results}

\subsection{Criminogenic characteristics of the monofunctional and transitional zones}

Open space crimes mostly concentrate in the high density monofunctional and polyfunctional zones of the target area. Only robberies and thefts show slightly different pattern - they are as often registered in the polyfunctional areas (Fig. 3). Average number of registered criminal incidents per cell is 19 in the residential and commercial zones and 18.5 in the polyfunctional zones. In the strongly monofunctional zones it is significantly higher: 23.8 in the zones with above $90 \%$ of residential use and 23.4 in the zones with above $90 \%$ of commercial use.

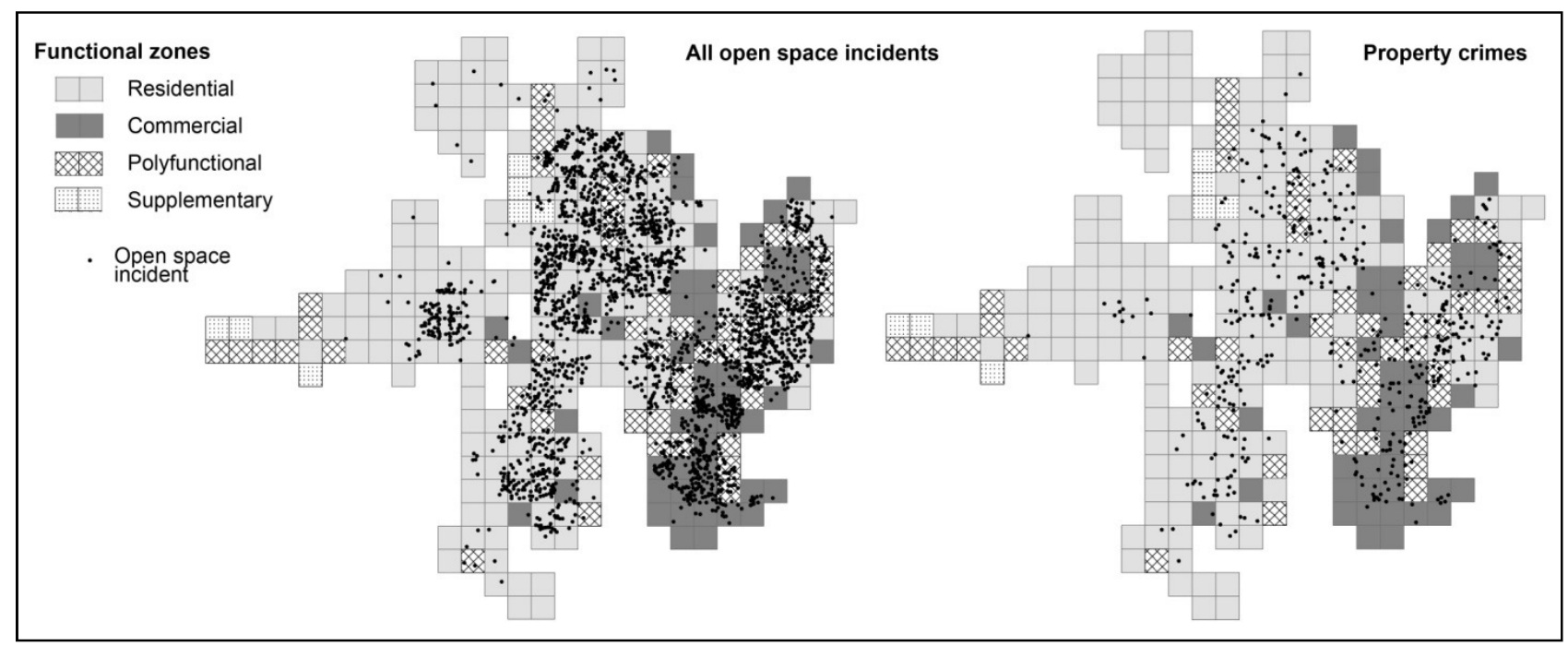

Fig. 3. Open space crimes in the functional zones

Cluster analysis showed that highest total number of criminal incidents has been registered in the strongly monofunctional commercial zone that is also closest to the city centre (south-eastern part of the target area - Naujamiestis). Urban space here can be characterized by lower visibility and by intense social interactions of people who come from neighbouring areas and do not belong to local communities. The most of incidents in this zone occur after the working hours. Besides that, heaviest offenses concentrate in this zone: $48 \%$ of violent crimes have been registered here.

Criminogenic situation in the residential zones varies. Some of them are organized in a way that is not opportune for criminal activities: optimized geometry of streets, larger visibility zones, well distributed infrastructural objects and public open spaces. Distance from the centre in this case is beneficial (Pilaitè, northern parts of Pašilaičiai and Fabijoniškès). Situation is worse in older residential districts (northern part of Žirmūnai, Viršuliškès, Šeškinè), partly due to sociodemographic characteristics of the population, but also to organization of urban environment: high concentration and 
monotonous configuration of the built-up areas (tower blocks of flats), closed yards and narrow side-streets, more complicated geometry of access to infrastructural objects - shops, schools, kindergartens etc., isolated and unfriendly open spaces.

Analysis of changes of criminality related to percentage of single use area in monofunctional zones (Table 1) revealed how crime rate by type depends on diversity of functions (Fig. 4).

Table 1. Distribution of different open space crimes across monofunctional and transitional areas

\begin{tabular}{|l|c|c|c|c|c|c|}
\hline & \multicolumn{2}{|c|}{ Minor offenses } & \multicolumn{2}{c|}{ Assaults } & \multicolumn{2}{c|}{ Murders } \\
\hline Zone & $/ 100$ inhabs. & $/ 1$ ha & $/ 100$ inhabs. & $/ 1$ ha & $/ 100$ inhabs. & $/ 1$ ha \\
\hline Commercial & \multicolumn{7}{|c|}{} \\
\hline$>60 \%$ & 48.92 & 12475 & 12.65 & 3225 & 1.57 & 400 \\
\hline $80-90 \%$ & 72.79 & 2675 & 38.78 & 1425 & 4.08 & 150 \\
\hline$>90 \%$ & 252.27 & 5550 & 22.73 & 500 & 11.36 & 250 \\
\hline Residential & 11.55 & 25725 & 0.86 & 1925 & 0.48 & 1075 \\
\hline$>60 \%$ & 9.72 & 19550 & 0.60 & 1200 & 0.30 & 600 \\
\hline $80-90 \%$ & 6.81 & 14425 & 0.84 & 1775 & 0.04 & 75 \\
\hline$>90 \%$ & \multicolumn{7}{|l|}{} \\
\hline
\end{tabular}

Commercial use
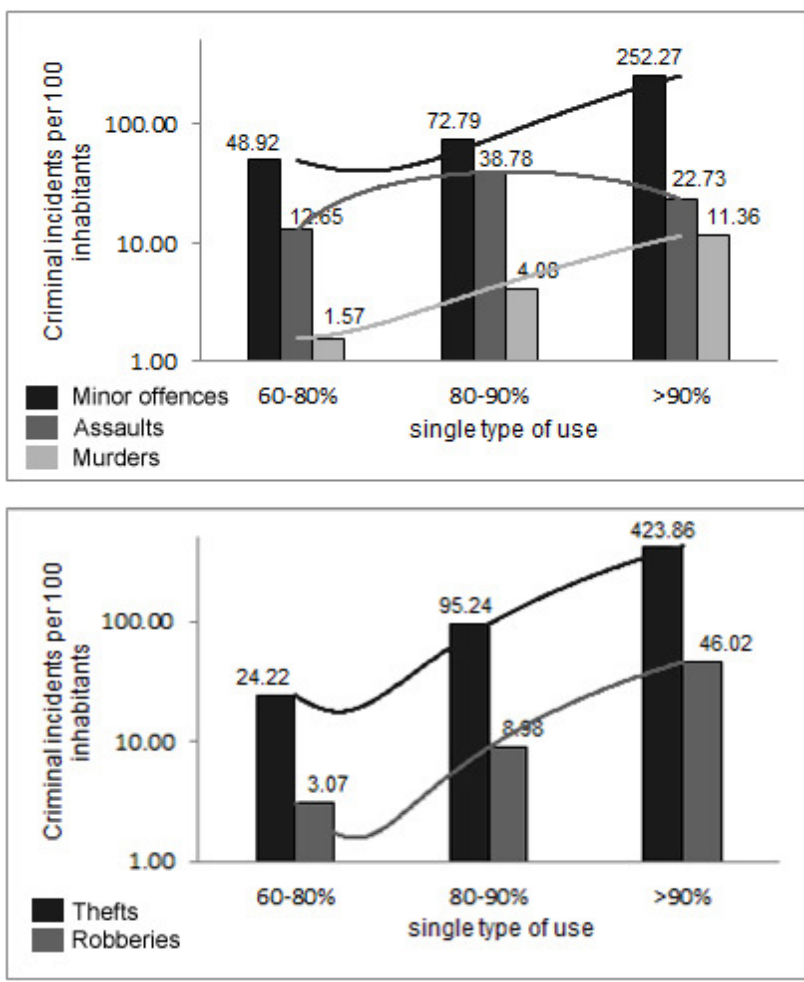

Residential use
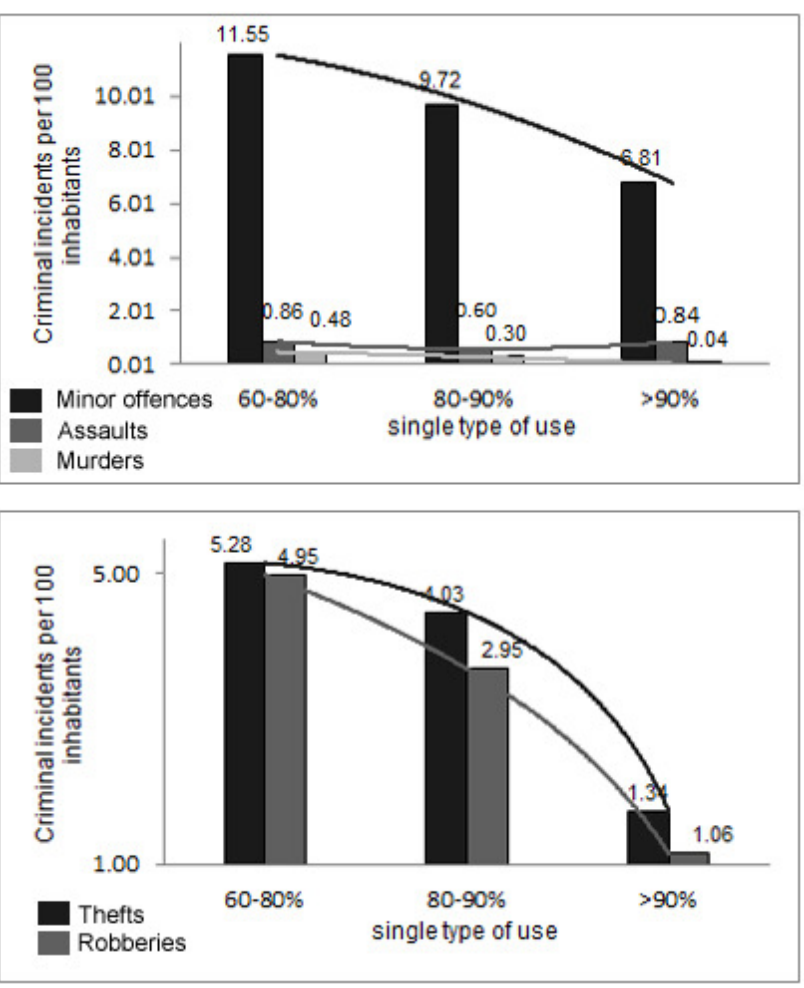

Fig. 4. Minor offenses, assaults, murders, thefts and robberies in the monofunctional zones

The percentage of solely commercial use is directly related to relative number of criminal incidents per 100 inhabitants (Fig. 4):

- Minor offenses (noise, conflicts, vandalism),

- Murders,

- Robberies and thefts.

The relative numbers of these types of incidents are especially higher in the purely commercial areas and almost linearly decrease in the commercial areas with $10-40 \%$ of other (mainly residential) use (Fig. 4). The number of assaults is slightly higher in the commercial areas with up to $20 \%$ of other use types.

The relationship between percentage of solely residential use and number of criminal incidents per 100 inhabitants is inverse for:

- Minor offenses,

- Murders,

- Robberies and thefts. 
It means that relative numbers of these two types of crimes grow with growth of mixed use. The number of assaults does not strongly depend on the proportion of types of use and this may be due to generally low relative number of assaults in the residential areas. The sharply decreasing relative number of thefts and robberies in the purely residential zone could be explained by better surveillance in the areas without commercial use.

\subsection{Dependency between crime rate and proximity to the city centre}

Distance from the geometrical centre point of city centre was calculated for all the cells of the target area. Due to distinguish the most characteristic areas, in the calculations areas with the lowest intensive of crimes were unappreciated. The result shows that the total number of registered crime incidents decreases with increasing distance from the centre (Fig. 5). However, there are exceptions to this rule, mainly at the crossings of major streets and in the neighbourhood of large shopping centres where the crime rate is higher regardless to proximity to the centre.

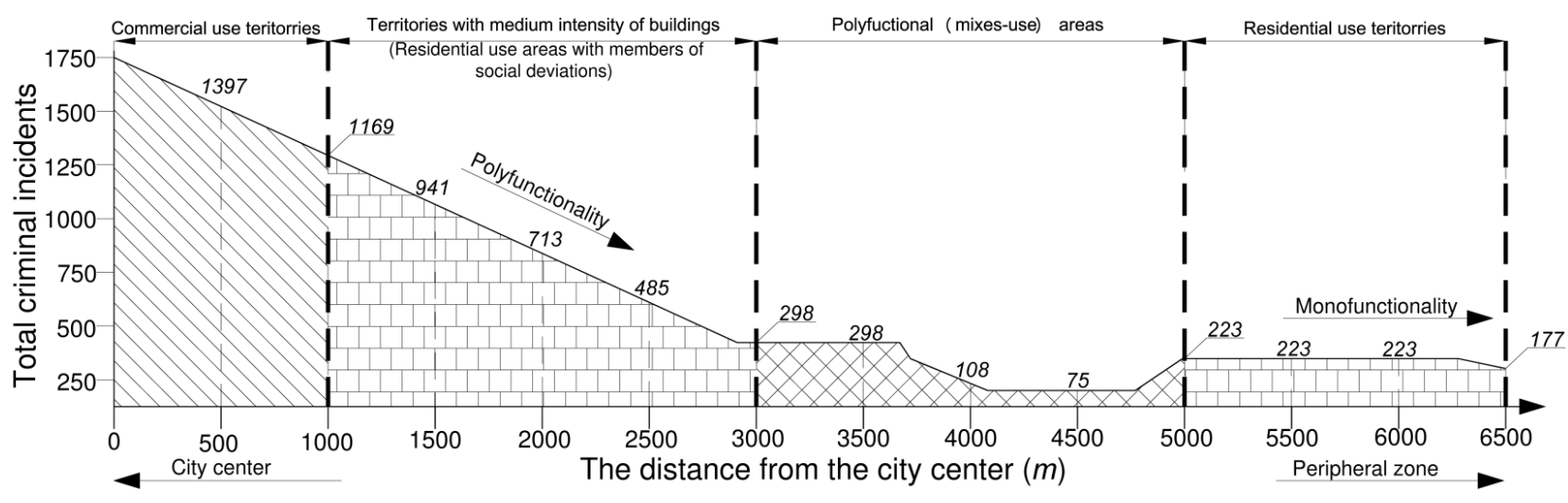

Fig. 5. Crime trend change evaluating the distance from the city centre

The simplified broken line in the graph above is divides into 4 parts which characterizes the main function of each group of areas. In the first part (city centre) the number of crimes uniformly decreasing throughout the part of territories with medium intensity of buildings where the multifunctionality proportional to the distance from the city centre grows up. This trend stops at the transition to city part which consist of pure polyfunctional areas, where the number of crimes directly depends on the locations of the main attraction centres. The crime trend keeps low level at the part of residential use territories and slightly decreasing in moving on the peripheral city zone.

With this calculation authors founds that polyfunctional territories are much safer than monofunctional ones in city centre and it approaches. In addition to that, high density residential uses territories shapes the safe environment in the scale of passing neighbourhood (together with network of D categories streets.

Authors found that the coefficient of correlation between total number of crimes and the distance from the city centre is 0.24 .

\section{Conclusions}

Analytical maps of crimes enable easy understanding the spatial structure of discovered dependencies, deeper insights and analysis of causalities. Together with spatial statistics, they allow revealing urban structures that are more or less opportune for conducting crimes in open spaces. The results can be used for urban planning that contributes to improvement of criminogenic situation in the city.

About two thirds of the analysed area of Vilnius city consists of monofunctional residential zones that are interspersed with small polyfunctional or commercial use areas along large streets. Only one part of the territory part can be considered a monofunctional commercial zone. $\mathrm{Bi}$ - and polyfunctional clusters are much smaller and only comprise $16.9 \%$ of the territory. Thus the residential districts of Vilnius mostly suffer from lack the variety of use whereas commercial use tends to concentrate in the areas closer to the city centre or near the intersections of important (mostly of them - rapid speed of A or B categories) streets.

Based on data of registered criminal incidents of 2012, Monofunctional residential and commercial zones of Vilnius have significantly higher overall crime rate than the zones with mixed use.

Monofunctional residential and commercial zones of Vilnius are much more exposed to open space crimes than bi- or polyfunctional zones.

Strongly monofunctional commercial zones ( $>80 \%$ of single use) are the most unsafe and characterized by specifically high rate of 'heavy' crimes (assaults, murders). The most of criminal incidents in these zones have been registered after the working hours, mainly in night time when the most of public spaces in these zones becomes empty and anonymous. 
Minor offenses prevail among open space crimes in monofunctional residential zones. The number of incidents increases with appearance of other types of use and depends on morphological and technical characteristics of urban environment. At low levels, increasing diversity of uses increases minor offenses, robberies and thefts in residential zones.

The number of crimes decreases from more central to peripheral areas of the target territory. This trend directly correlated to the urban structure with various functional zones in Vilnius city. The coefficient of correlation between total number of crimes and the distance from the city centre is -0.24 .

\section{Acknowledgements}

We are grateful to Prof. Dovilè Krupickaitè of Vilnius University for sharing the data on functions in Vilnius buildings.

\section{References}

[1] Antonucci, T. C.; Akiyama, H. 1991. Convoys of social support: generation issues, in Pfeifer, Susan K., Sussman, M.B. Marriage and Family Review, $103-124 \mathrm{p}$.

[2] Atlas, R. (Ed). 2008. 21st Century Security and CPTED: Designing for Critical Infrastructure Protection and Crime Prevention, CRC Press, Taylor \& Francis Ltd. http://dx.doi.org/10.1201/9781420068085

[3] Beconytè, G.; Eismontaite, A. 2012. Analytical Mapping of Registered Criminal Activities in Vilnius City, Geodesy and Cartography (Geodezija ir kartografija) 38(4): 134-140. http://dx.doi.org/10.3846/20296991.2012.755343

[4] Badger, E. 2013. Mixed-Use Neighborhoods May Be Safer, Too. Available from Internet: http://www.theatlanticcities.com/neighborhoods/2013/03/mixed-use-neighborhoods-may-be-safer-ones-too/4962/

[5] Brantingham, P. L.; Brantingham, P. J. 1981. Notes on the Geometry of Crime, in Environmental Criminology, edited by Paul J. Brantingham and Patricia L. Brantingham. Beverly Hills: Sage.

[6] Bristol, K. G. 1991. The Pruitt-Igoe Myth. University of California, Berkeley. http://www.pruitt-igoe.com/temp/1991-bristol-pruitt-igoemyth.pdf (last visited 2013-05-01)

[7] Clarke, R. V. 1997. Situational Crime Prevention: Successful Case Studies. Second edition. Albany, NY: Harrow and Heston.

[8] Cohen, L. E.; Felson, M. 1979. Social Change and Crime Rate Trends: A Routine Activity Approach, American Sociological Review 44: 588-605. http://dx.doi.org/10.2307/2094589

[9] Eck, J. E. 1994. Drug Markets and Drug Places: A Case-Control Study of the Spatial Structure of Illicit Drug Dealing. Unpublished Ph.D. dissertation, University of Maryland, College Park.

[10] Felson, M. 1994. Crime and Everyday Life: Insight and Implications for Society. Thousand Oaks, CA: Pine Forge Press.

[11] Felson, M.; Boba, R. 1998. Crime and Everyday Life. Second Edition. United States of America: Sage Publications. 251 p.

[12] Fisher, B.; Gullen, F.; Turner, M. 2001. The Sexual Victimization of College Women. Washington, DC: National Institute of Justice.

[13] Gans, J. H. 1962. The Urban Villagers. New York: Free Press of Glencoe. 367 p.

[14] Jeffery, C. R. 1971. Crime Prevention Through Environmental Design. Beverly Hills, CA: Sage Publications.

[15] Jeffery, C. R. 1990. Criminology: An Interdisciplinary Approach. Englewood Cliffs, NJ: Prentice-Hall.

[16] Newman, O. 1972. Defensible Space: Crime Prevention Through Urban Design. New York: Macmillan.

[17] Paulsen, D. J.; Robinson, M. B. 2008. Spatial aspects of crime: Theory and practice. $2^{\text {nd }}$ ed. Boston: Pearson

[18] Paulsen, D. J. 2013. Crime and planning, Building socially sustainable communities, CRC press.

[19] Schneider, R. H.; Kitchen, T. 2008. Crime Prevention and the built environment. Routledge. 18 p.

[20] Siegel, L. J. 2011. Criminology. Eleventh edition. Stamford, Connecticut: Cengage Learning. 715 p.

[21] Stevenson, F.; Williams, N. 2007. Sustainable housing design guide for Scotland. Edinburgh: Communities Scotland. Available from Internet: http://www.archive2.official-documents.co.uk/document/deps/cs/shdg/ch02/index.html

[22] Lewis, H. LaRue. 1974. Defensible Space, By Oscar Newman, 31 Wash. \& Lee L. Rev. 809. 